\title{
初期ねじれを有する長柱および梁の振動特性に関する研究
}

\author{
宮本 博司 ${ }^{* 1}$, 渡邊 鉄也 ${ }^{* 2}$, 鞆田 顕章 ${ }^{* 3}$
}

\section{Study on the vibration characteristics of the pre-twisted pillar and beam}

\author{
Hiroshi MIYAMOTO*1 ${ }^{* 1}$ Tetsuya WATANABE ${ }^{* 2}$ and Akinori TOMODA*3 \\ ${ }^{* 1}$ Canon Inc. \\ 3-30-2 Shimo-maruko, Ota-ku, Tokyo, 146-0092 Japan \\ ${ }^{* 2,{ }^{3}}$ Saitama Univ. Dept. of Mechanical Engineering \\ 255 Shimo-okubo, Sakura-ku, Saitama-shi, Saitama, 338-8570 Japan
}

Received 9 March 2014

\begin{abstract}
For the past several years, large scale earthquakes happened. A lot of industrial facilities were damaged. For example, a lot of power plants were stopped in The 2011 off the Pacific coast of Tohoku Earthquake or The Southern Hyogo prefecture earthquake in 1995. These earthquakes have larger acceleration level than the seismic design level. Therefore, the earthquake proof measures are required. In this study, earthquake proof effect of the beam and the long column having initial twist is focused. The design guidelines for application to the pre-twisted beam structure and the long column structure is proposed. The pre-twisted beam and long column are modelled by FEM and calculated. The natural frequency of the pre-twisted beam and long column are related to the Young's modulus, density, length and cross-sectional area. The tendency of the natural frequency respected to the total twisted angle and the aspect ratio of the cross-section is obtained considering the vibration mode and the natural frequency. Furthermore, when attention is focused on the vibration mode, the influence of the total twisted angle is different for the modal shapes, and the case where the modal shapes are interchanged is shown. The acceleration response to the vibration input is determined by the natural frequency of the primary cross-section, the aspect ratio and boundary conditions. In order to evaluate the response reduction effect, the acceleration amplification respected to the total twisted angle and the $1^{\text {st }}$ natural frequency of the system is analyzed. And the response reduction map is proposed. Using this map, it is possible to estimate the advantage of the pre-twisted effect for the vibration characteristics in a simple manner.
\end{abstract}

Key words : Pre-twisted beam, Natural frequency, Seismic motion, Seismic design, Response reduction effect

\section{1. 緒言}

近年，兵庫県南部地震(1995)や新潟県中越地震(2004)あるいは東北地方太平洋沖地震(2011)などをはじめとする 大規模な地震が多発しており，一般家屋もさることながら産業施設内構造物の被害も多く報告されている．産業 施設内構造物は 2 次的な災害が懸念されるため，一般家屋とは異なる耐震設計基準が定められている. 最近の地 震は，日本がこれまで経験したことがないような振動であり，耐震設計基準で定められている地震の加速度レベ ルをはるかに超えている．したがって，地震対策が急務であるとされている．地震対策としては，減衰要素を用 いて応答低減させる方法や地震荷重の伝達を軽減する免震設計，剛性を増加させる而震設計などがある．筆者ら は，これまでの研究(渡邊他,1992,1996,2006, 渡邊,鈴木,1998a,1998b,2000, 鞆田他,2007)において, 摩擦のエネルギ

No.14-00136 [DOI: 10.1299/transjsme.2014dr0169]

*1 正員，キャノン株式会社（率146-0092 東京都大田区下丸子 3-30-2)

$*_{2}$ 正員，フェロー，埼玉大学大学院理工学研究科（†338-8570 埼玉県さいたま市桜区下大久保 225）

*3 正員, 埼玉大学大学院理工学研究科

E-mail of corresponding author: watanabe@mech.saitama-u.ac.jp 
散逸効果に注目して応答低減効果を明らかにしてきた。また，エネルギに注目して衝突現象による応答低減効果 を評価してきた(渡邊他,2008)。さらに, 繰返し荷重における弾塑性系に注目した応答スペクトルを示してきた(渡 邊他,2009). 本研究では, 而震設計に着目し，長柱や梁をねじることによる剛性の増加や振動モードの変化によ る応答低減効果に注目した，軸周りに初期ねじれを有する長柱および梁に関しては，ジェットエンジンのタービ ンブレードの形状に近いことから，自由振動解析に必要な基礎理論を定式化した例（板倉,築地,1993, 板倉,1996） や，振動について検討を行った例（Liu,K-C, et al., 2009）, 軸圧縮座屈荷重や風荷重における優位性について検討 を行った例が存在する.しかし，振動特性の観点から構造物への応用方法について検討した例は発表されていな い. 振動特性の観点から構造物に初期ねじれを有することによる優位性を証明し適用できれば，地震に対する耐 震性の向上に応用が可能であると考えられる. そこで, 本研究は, 初期衴じれを有する長柱および梁について, 初期ねじれによる振動特性を明らかにし, 而震設計への適用方法を提案する.

\section{2.＼cjkstart初期ねじれを有する長柱および梁の有限要素モデル}

本研究では, 中心軸周りにねじれを有する長柱および梁を考える. 解析は有限要素モデル(Bathe and Wilson,1996, ツィエンキーヴィッツ,テイラー,1996, 山田,2011)を用いて行う. 図 1 のように 3 次元はり要素を, 少しずつ秝じ りながら接合することにより, 初期ねじれ柱を実現する. 総ねじれ角から分割した 1 要素あたりのねじれ角を算 出し, 座標変換マトリクスを用いて要素ごとに回転させる. $i$ 番目の要素のねじれ角 $\theta_{l}$ は以下の式で算出できる. ここで, $\theta$ は総㸚じれ角 (部材両端の角度差), $n$ は分割数である. プログラム作成では MATLAB を用いている.

$$
\theta_{i}=\frac{2 i-1}{2 n} \theta
$$

\section{3. 初期ねじれを有する長柱および梁の基本特性}

\section{$3 \cdot 1$ 解析条件}

系の特性を定める各パラメータが, 初期ねじれを有する部材の固有振動数とどのような関係があるか検討する. ここでは, 系の特性を定めるパラメータとして, 縦弾性係数 $E$, 密度 $\rho$, 長柱・梁の長さ $L$, 断面積 $A$, 断面辺 長比 $\gamma$ 考える. 解析条件を表 1 に示寸.

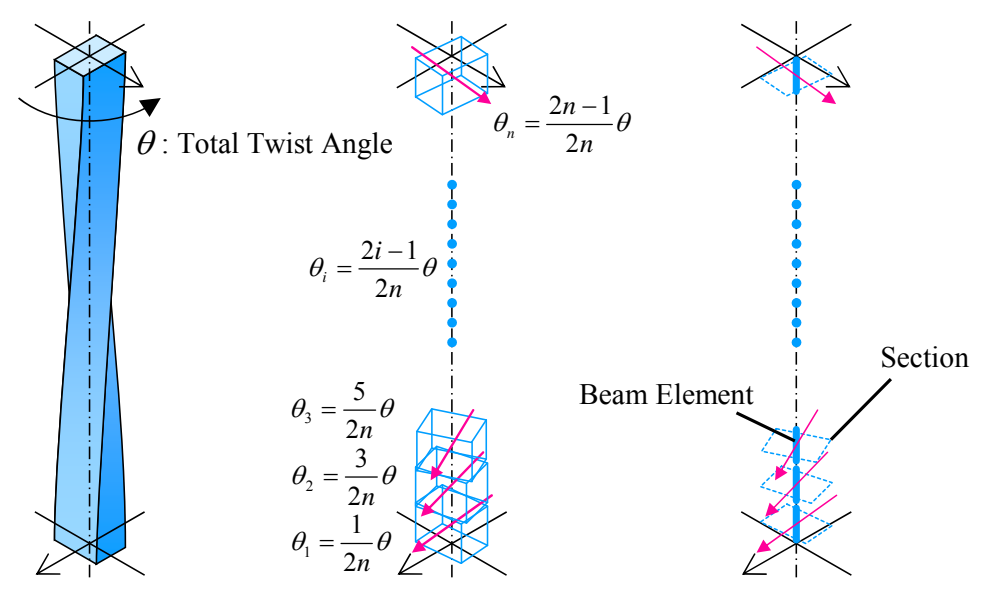

Pre-Twist Pillar or Beam

Divide $(n)$

FEM (Beam Element)

Fig. 1 FE Modeling of Pre-Twisted Pillar and Beam. Three dimensional beam twisted elements are connected. Twisted angle of one element is calculated from the total twisted angle, and rotated by coordinate transform matrix. 


\section{$3 \cdot 2$ 解析結果および考察}

解析結果の例（片持ち，断面辺長比 2) を図 2 に示す. 図 2(a)～図 2(d)は，それぞれ，総ねじれ角が $0, \pi ， 2$ $\pi, 3 \pi[\mathrm{rad}]$ の場合で, 縦軸に固有振動数, 横軸に縦弾性係数とし, 1 次モード〜4 次モードの固有振動数をプロ ットしたものである，縦弾性係数，密度，長さ，断面積と固有振動数には比例関係があることがわかった．固有 振動数は，縦弾性係数を変化させた場合には縦弾性係数の $1 / 2$ 乗に比例，密度を変化させた場合には密度の-1/2 乗に比例, 長さを変化させた場合には長さの-2 乗に比例, 断面積を変化させた場合には断面積の $1 / 2$ 乗に比例し た. 固有振動数を $f$, 系の長さを $L$, 断面積を $A$, 縦弾性係数を $E$, 密度を $\rho$ とし, これらの比例関係を式で表す と, 式(2)のようになる. 図 2 の曲線は式(2)を用いて近似した曲線である.この比例関係は境界条件や総ねじれ角, 断面辺長比によらないことがわかった. 初期ねじれの無い場合については解析解(入江,小林,2009)からこの比例関 係が得られるが，初期ねじれを有する場合についてもこの関係式が成り立つことがわかった.

$$
f \propto \frac{1}{L^{2}} \sqrt{\frac{E A}{\rho}}
$$

Table 1 Analysis Condition

\begin{tabular}{|c|c|c|c|c|c|c|}
\hline $\begin{array}{c}\text { Young's modulus } \\
\qquad E[\mathrm{GPa}] \\
\end{array}$ & $\begin{array}{c}\text { Density } \\
\rho\left[\mathrm{kg} / \mathrm{m}^{3}\right] \\
\end{array}$ & $\begin{array}{l}\text { Length } \\
L[\mathrm{~m}] \\
\end{array}$ & $\begin{array}{c}\text { Area } \\
A\left[\mathrm{~m}^{2}\right]\end{array}$ & $\begin{array}{c}\text { Aspect Ratio } \\
\gamma[-] \\
\end{array}$ & $\begin{array}{l}\text { Total Twisted Angle } \\
\qquad \theta[\mathrm{rad}]\end{array}$ & $\begin{array}{l}\text { Boundary } \\
\text { Condition }\end{array}$ \\
\hline $10-80$ & 2700 & 10 & \multirow{3}{*}{$1.0 \times 10^{-4}$} & \multirow{4}{*}{$1,2,5,10$} & \multirow{5}{*}{$0, \pi, 2 \pi, 3 \pi, 4 \pi, 5 \pi$} & \multirow{5}{*}{$\begin{array}{l}\text { Cantilever } \\
\text { Pined-Pined } \\
\text { Fixed-Fixed } \\
\text { Fixed-Pined }\end{array}$} \\
\hline \multirow{4}{*}{70} & $500-3000$ & 1.0 & & & & \\
\hline & \multirow{3}{*}{2700} & $1.0-5.0$ & & & & \\
\hline & & \multirow[t]{2}{*}{1.0} & \multirow[t]{2}{*}{$1.0 \times 10^{-4}-10^{-3}$} & & & \\
\hline & & & & $1-10$ & & \\
\hline
\end{tabular}

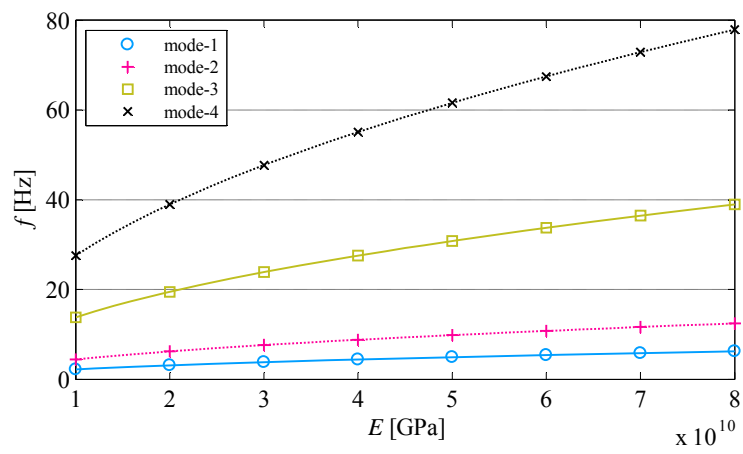

(a) $\theta=0[\mathrm{rad}]$

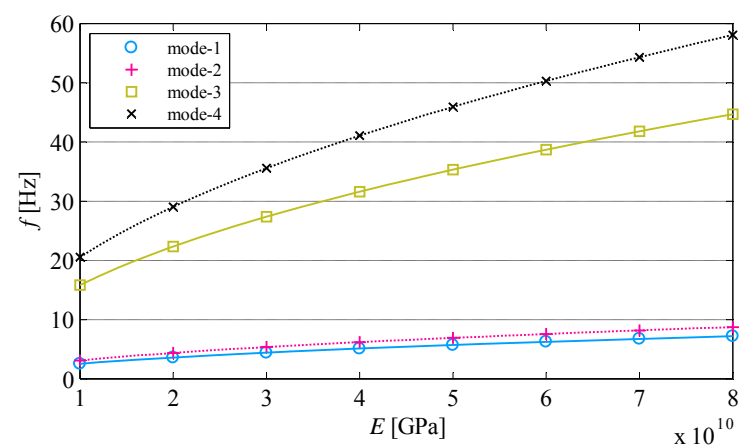

(c) $\theta=2 \pi[\mathrm{rad}]$

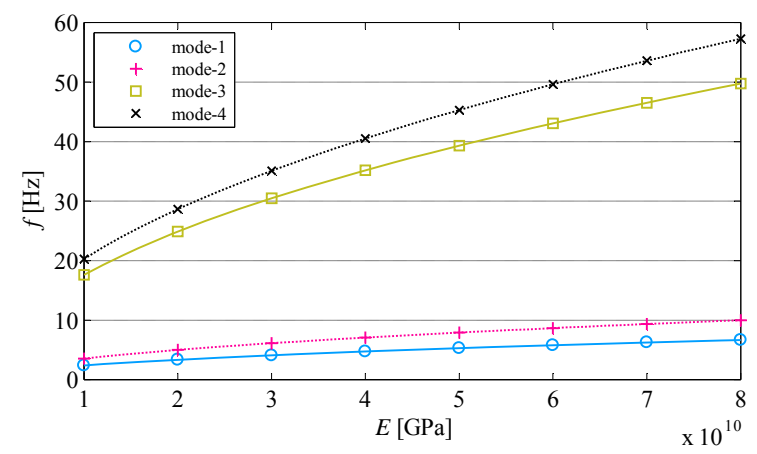

(b) $\theta=\pi[\mathrm{rad}]$

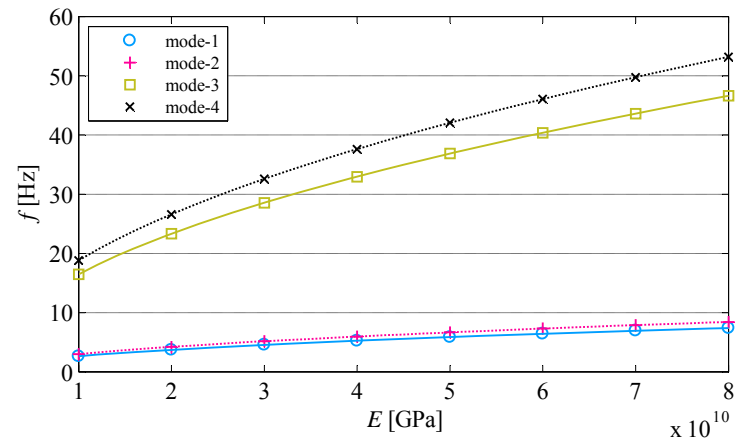

(d) $\theta=3 \pi[\mathrm{rad}]$

Fig. 2 The natural Frequency with respect to parameter (Cantilever $\gamma=2$ ). Figures 2(a) to 2(b) are the case that the twisted angle is $0, \pi, 2 \pi$ and $3 \pi[\mathrm{rad}]$, respectively. Vertical axis is natural frequency and horizontal axis is Young's modulus. Natural frequencies of 1 st mode to 4 th mode are plotted. It is apparent that natural frequency is in proportion to Young's modulus, density, length and cross-section area. 


\section{4. 初期ねじれを有する長柱および梁の振動特性}

\section{$4 \cdot 1$ 解析条件}

3 章の結果から，固有振動数と $E, \rho, L, A$ には比例関係があることがわかった. 次に，断面辺長比と総ねじ れ角による固有振動数の変化の傾向について検討する. 断面辺長比と総ねじれ角を変化させて固有振動数を解析 する場合のパラメータを表 2 に示す. 材質はアルミニウムとし, 縦弾性係数, ポアソン比, 密度はそれぞれ, 70Gpa, $0.34,2700 \mathrm{Kg} / \mathrm{m}^{3}$ とした.

\section{$4 \cdot 2$ 解析結果および考察}

解析結果を図 3 に示す. 左図は縦軸を断面辺長比 $\gamma$, 横軸を総ねじれ角 $\theta$ として 1 次の固有振動数を色分けし たものであり，右図は断面辺長比を変化させた場合の，総ねじれ角による 1 次，2 次の固有振動数を示したもの である。

断面辺長比が 1 (正方形断面）の条件では，総ねじれ角により固有振動数は変化しないが，断面辺長比が 1 よ り大きい条件では，総ねじれ角により固有振動数が変化することが確認できる. 総ねじれ角の増加に伴い 1 次モ 一ドと 2 次モード同士が収束し，一定の值に収束することが確認できる．境界条件が異なっても，収束する傾向 があることを確認した。

次に，振動モードに着目する.片持ち条件の 1 次の振動モードを総ねじれ角が $0,2 \pi[\mathrm{rad}]$ で，断面辺長比 $\gamma=10$ の場合の振動モードを図 4 に示す.ねじれの無い場合は y-z 面内の振動モードとなっているが，ねじれのある場 合では，3 次元の振動モードとなっている. 3 次元の振動モードになる理由としては，初期ねじれにより各部分の 断面 2 次モーメントが大きい方向と小さい方向が変化するためであると考えられる.

Table 2 Analysis Condition

\begin{tabular}{|c|c|c|c|c|c|}
\hline Material & $\begin{array}{c}\text { Length } \\
L[\mathrm{~m}]\end{array}$ & $\begin{array}{c}\text { Area } \\
A\left[\mathrm{~m}^{2}\right]\end{array}$ & $\begin{array}{c}\text { Aspect Ratio } \\
\gamma[-]\end{array}$ & $\begin{array}{c}\text { Total Twisted Angle } \\
\theta[\mathrm{rad}]\end{array}$ & $\begin{array}{c}\text { Boundary } \\
\text { Condition }\end{array}$ \\
\hline & 1.0 & $1.0 \times 10^{-4}$ & $1-100$ & $0-10 \pi$ & $\begin{array}{c}\text { Cantilever } \\
\text { Pined-Pined } \\
\text { Fixed-Fixed } \\
\text { Fluminum }\end{array}$ \\
\hline
\end{tabular}

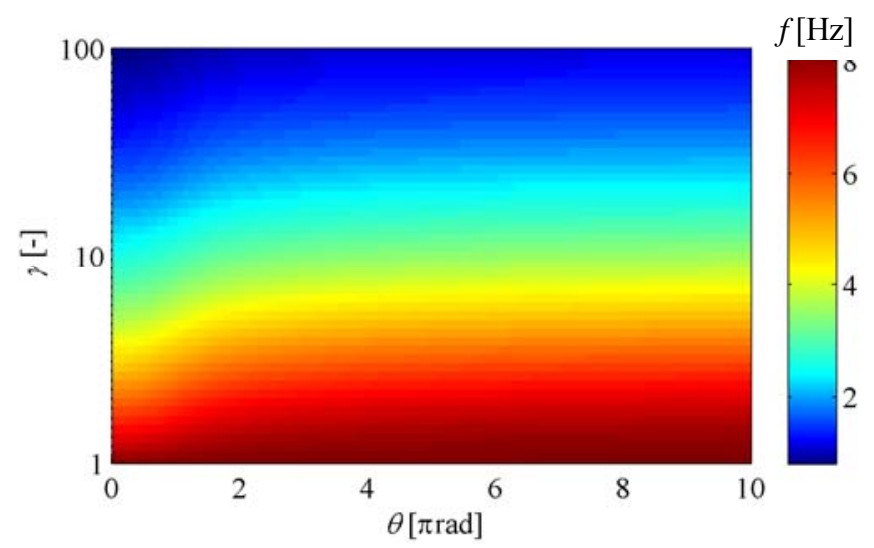

(a)Frequency of $1^{\text {st }}$ Vibration Mode

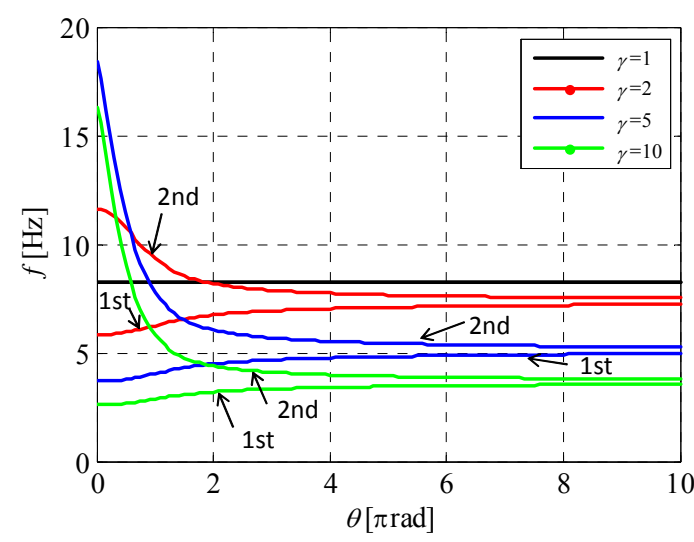

(b)Frequency of $1^{\text {st }}-2^{\text {nd }}$ Vibration Mode

Fig. 3 Frequency with respect to pre-twisted (Cantilever). Fig.3(a) is the relation between cross-sectional side-length ratio $\gamma$ and total twisted angle. Fig.3(b) is the relation between natural frequency and total twisted angle with respect to $\gamma$. It is apparent that natural frequencies of 1 st and 2 nd mode converge with increase of twisted angle. 

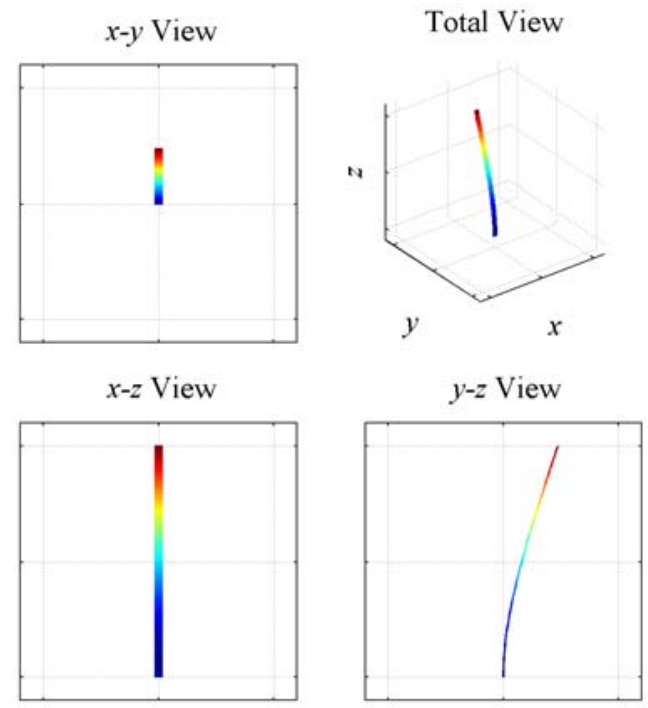

(a) $\theta=0 \pi$
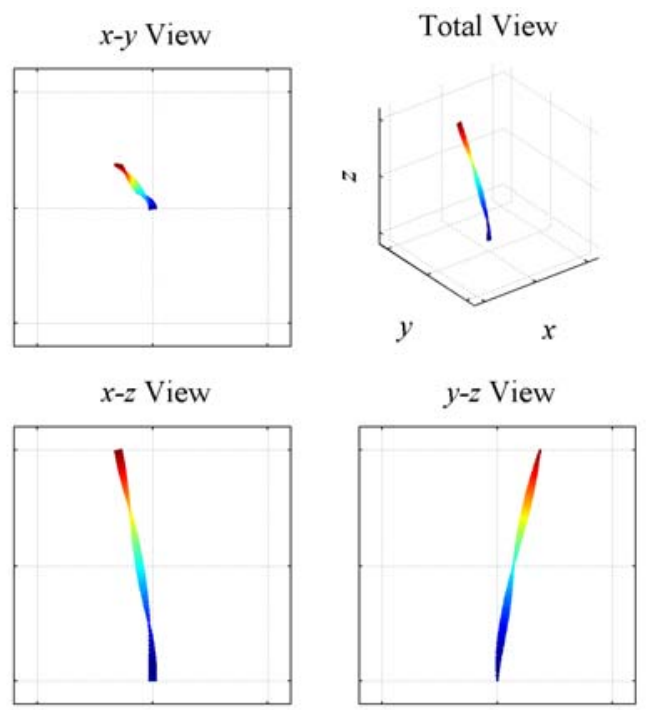

(b) $\theta=2 \pi$

Fig. $4 \quad 1^{\text {st }}$ Vibration Mode of Non-Twisted and Pre-Twisted (Cantilever, $\gamma=10$ ). Fig.4(a) and (b) show the non-twisted mode and twisted mode, respectively.

\section{5. 初期ねじれ角が無限に近づく場合の収束值}

\section{$5 \cdot 1$ 解析条件}

総ねじれ角を大きくした場合，剛性の最大值と最小值の差が減少してある值に収束する．また，固有振動数は 1-2 次モード, 3-4 次モードの組み合わせで収束する. この収束の傾向について検討する. 剛性および固有振動数 が概ね収束している $\theta=100 \pi$ を初期ねじれが無限に近づく $\theta \rightarrow \infty$ と考え, その場合の剛性および固有振動数と断 面辺長比の関係を調べる. 解析条件を表 3 に示す. 分割数は 500 として, 剛性では最大值と最小值の平均值, 固 有振動数では 1-2 次モード, 3-4 次モードの平均值を用いる.

Table 3 Analysis Condition

\begin{tabular}{|c|c|c|c|c|c|}
\hline Material & $\begin{array}{c}\text { Length } \\
L[\mathrm{~m}]\end{array}$ & $\begin{array}{c}\text { Area } \\
A\left[\mathrm{~m}^{2}\right]\end{array}$ & $\begin{array}{c}\text { Aspect Ratio } \\
\gamma[-]\end{array}$ & $\begin{array}{c}\text { Total Twisted Angle } \\
\theta[\mathrm{rad}]\end{array}$ & $\begin{array}{c}\text { Boundary } \\
\text { Condition }\end{array}$ \\
\hline & & & & & $\begin{array}{c}\text { Cantilever } \\
\text { Pined-Pined } \\
\text { Aluminum }\end{array}$ \\
& 1.0 & $1.0 \times 10^{-4}$ & $1-100$ & $100 \pi$ & Fixed-Fixed \\
& & & & Fixed-Pined \\
\hline
\end{tabular}

\section{$5 \cdot 2$ 収束値の解析結果}

片持ち条件における解析結果を図 5 に示寸．図 5(a) は縦軸に剛性，横軸に断面辺長比，図 5(b)は縦軸が固有振 動数, 横軸が断面辺長比である. これらの図から断面辺長比による変化傾向が同じであることがわかるため, 断 面辺長比が 1 の時の岡性および固有振動数に対する比をとった結果を図 6 に示寸. 図 6(b)からモード次数にかか わらず同じ曲線になっていることがわかる. また，この傾向は境界条件を変化させた場合でも同様に得られた. 総ねじれ角が無限に近い部材は, 一定の断面積で断面辺長比を変化させた場合, 断面辺長比が大きいほど岡性お よび固有振動数が減少していることがわかる. 
初期ねじれが無限に近い場合で固有振動数が収束している場合は異方性がないことから，このねじれ部材と同 じ岡性や固有振動数を有する正方形断面の部材について検討する. 長さ $L$ の正方形断面の片持ち梁においては, 剛性 $K$ と断面積 $A$ の関係は式(3), $i$ 次の固有振動数 $f_{i}$ と断面積 $A$ の関係は式(4)となる.

$$
\begin{aligned}
& A=\sqrt{\frac{4 L^{3}}{E} K} \\
& A=\frac{48 \pi^{2} L^{4} \rho}{\lambda_{i}^{4} E} f_{i}^{2}
\end{aligned}
$$

この式から, 初期ねじれが無限の場合について, 元の断面積を $A$, 等価な特性を持つ正方形断面の断面積を $A_{\mathrm{eq}}$, 係数を $\beta_{K}$ (剛性) および $\beta_{f}$ (固有振動数) とし，式(5)のように表すと， $\beta_{K}$ および $\beta_{f}$ は図 7 のようになる.

$$
\left\{\begin{array}{l}
\left.A_{\mathrm{eq}}=\beta_{K} A \text { (剛性 }\right) \\
\left.A_{\mathrm{eq}}=\beta_{f} A \text { (固有振動数 }\right)
\end{array}\right.
$$

図 7 より, $\beta_{K}$ と $\beta_{f}$ の関係は $\beta_{K}{ }^{2}=\beta_{f}$ となり, 誤差は $0.034 \%$ あっった. 図 7 を近似式で表すと式(6)のようになる.

$$
\beta_{K}{ }^{2}(\gamma)=\beta_{f}(\gamma)=0.527 e^{-1.81\left(\log _{10} \gamma\right)^{2}}+0.277 e^{-5.56\left(\log _{10} \gamma\right)^{2}}+0.196 e^{-0.574\left(\log _{10} \gamma\right)^{2}}
$$

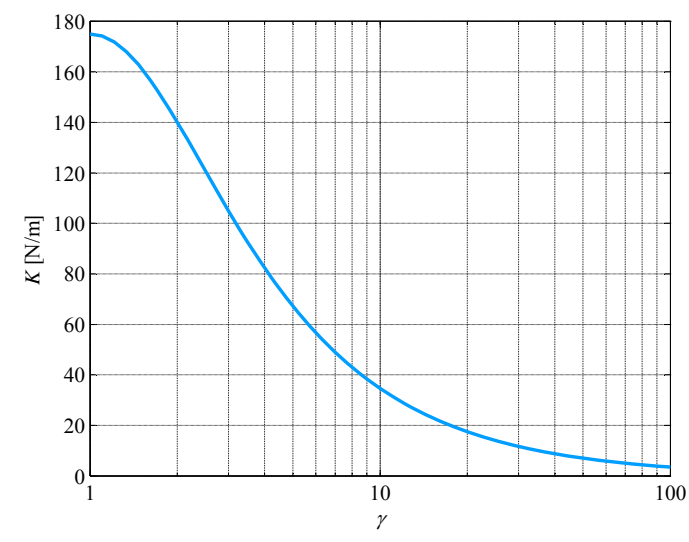

(a) Stiffness

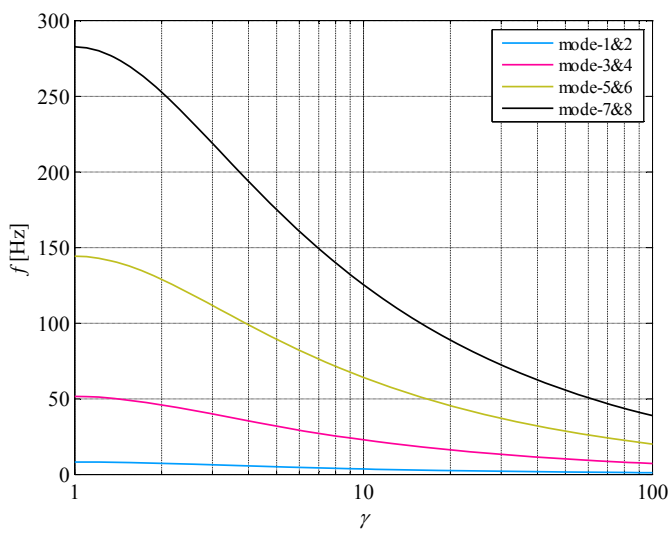

(b) Frequency

Fig. 5 Convergence Properties of Infinite Total Twisted Angle (Cantilever). It is apparent that the change trend of stiffness and frequency respected to $\gamma$ is similar.

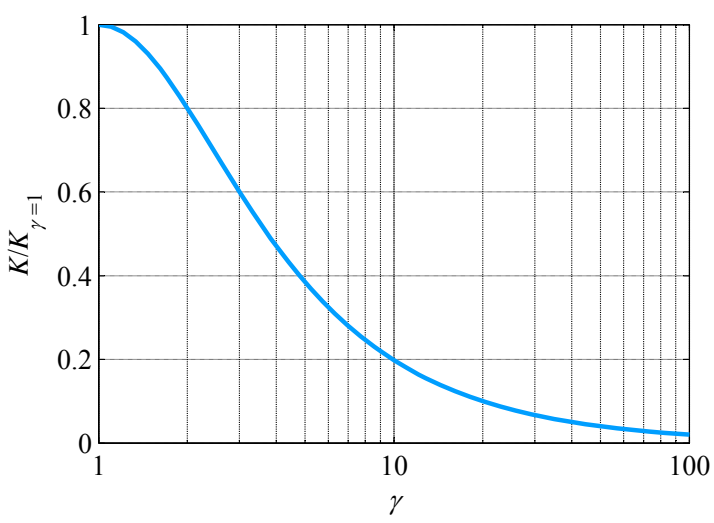

(a) Stiffness Ratio

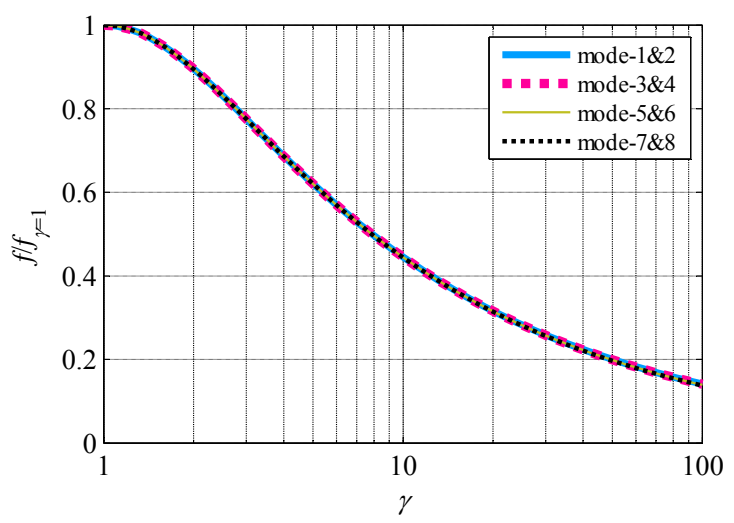

(b) Frequency Ratio

Fig. 6 Convergence Properties of Infinite Total Twisted Angle (Ratio, Cantilever). The ratio of stiffness and natural frequency in the case of $\gamma=1$ is represented. The ratio of frequency is same in spite of modes. 


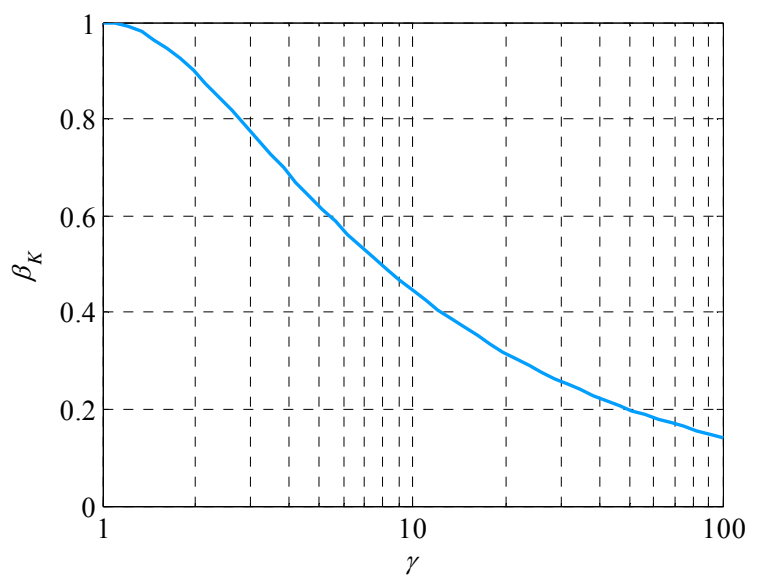

(a) Stiffness Factor $\beta_{K}$

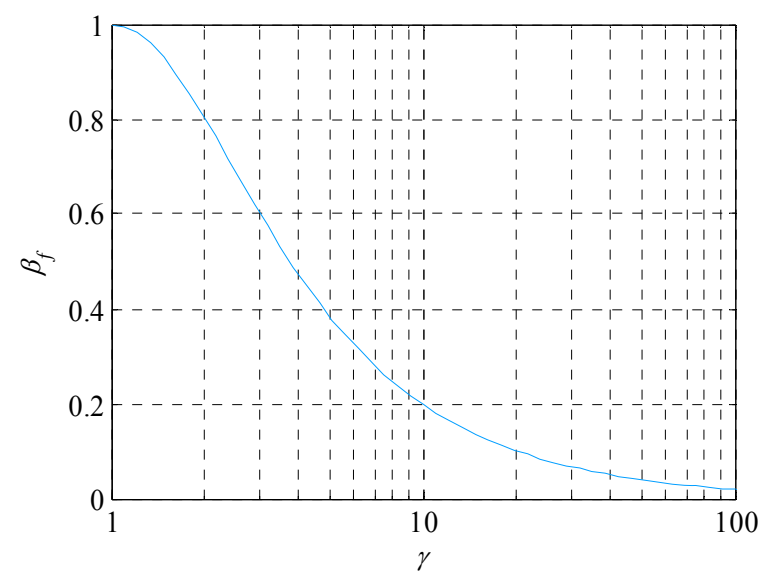

(b) Frequency Factor $\beta_{f}$

Fig. 7 Infinite Total Twisted Angle Factor (Cantilever). Stiffness and natural frequency converge when the total twisted angle goes to infinite. Equivalent cross-sectional area of square can be calculated using Fig.7.

\section{6.＼cjkstart初期ねじれを有する長柱および梁の応答低減効果}

\section{$6 \cdot 1$ 実地震波入力に対する応答解析条件}

初期ねじれを有する部材に実地震波を入力した場合にどのような特徵があるかについて，簡易耐震設計に応用 する観点から加速度応答倍率により検討を行う. 加速度応答倍率は, 最大応答加速度を最大入力加速度で割った 值とし，その計算に使用する加速度は，片持ち条件では先端，両端固定条件では中央部とし，2 方向のベクトル 和とする. 入力波は 1940 年 Imperial Valley 地震 El Centro における地震波用い，部材に垂直な面上の 2 方向（東 西方向と南北方向）に入力した．また，入力波の方向を変えて 2 通りの解析を行い，それぞれで計算した加速度 応答倍率の平均值を用いた。 解析条件を表 4 に示寸.

\section{$6 \cdot 2$ 実地震波入力に対する応答解析結果および考察}

解析結果の例を図 8 に示寸. 図の縦軸はねじれのない場合の 1 次の固有振動数, 横軸は総ねじれ角とし, 加速 度応答倍率の大きさを色分けしている. 図 8(a)〜図 8(d)は断面辺長比 $\gamma$ がそれぞれ 1,2,5,10 の場合である.

解析結果より, 加速度応答倍率は総ねじれ角が $4 \pi$ を超えた辺りから大きな変化がなくなることや, 断面辺長比 が大きいほど初期ねじれの変化による加速度応答倍率の変化が大きくなる傾向が見られる. また, 加速度応答倍 率の大きい領域は, 地震波の卓越振動数と関係があり, 初期致じれを有することで地震波の卓越振動数に系の固 有振動数が近づく場合は加速度応答倍率の増加, 逆に離れる場合は減少しているものと考えられる. 総ねじれ角 が $4 \pi$ 程度となると, 系の固有振動数が 1-2 次モード, 3-4 次モードの組合せで近い值となるため, 加速度応答倍 率の大きい領域と小さい領域が顕著に表れるものと考えられる.

初期ねじれを有する部材に地震波を入力した際には, 系の固有振動数と地震波の卓越振動数の関係から加速度 応答倍率の増加や減少が見られた。このことから, 加速度応答倍率が減少するようなパラメータを設定すること により，構造物に初期衴じれを有利に応用できる可能性がある.

\section{$6 \cdot 3$ 模擬地震波入力に対する応答解析条件}

実地震波を用いた解析では一般性がないため, 模擬地震波(高圧ガス保安協会,2012, 日本機械学会,1990, 大 崎,2004)を用いて応答解析を行う. 本研究では, 高圧ガス施設等而震設計指針の第 1 種地盤から第 4 種地盤に対 応した 4 種類について, 設計用加速度応答スペクトルに適合させた模擬地震波を入力波として使用する. なお, 入力する模擬地震波は入力方向あたり 5 波用意して, それぞれの加速度応答倍率を計算し, その平均値を用いる. 解析条件は 6.1 節と同様に表 4 とした. 


\section{$6 \cdot 4$ 模擬地震波入力に対する応答解析結果および考察}

第 1 種地盤の模擬地震入力に対する片持ち条件の加速度応答倍率の解析結果を図 9 と図 10 に示す. 図 9 は断面 辺長比が 10,1 次の固有振動数が $0.1[\mathrm{~Hz}]$ と $1[\mathrm{~Hz}]$ の場合で, 各節点について加速度応答倍率の大きさを表したも のであり, 図中左側が固定側となっている. 図 10 は加速度応答倍率の計算結果であり, 縦軸にねじれのない場合 の 1 次の固有振動数, 横軸に総ねじれ角をとり, 加速度応答倍率の大きさを色分けしている.

図 9 より, 1 次の固有振動数が低い図 9(a) においては, 高次の振動モードの影響が大きく現れており, 形状が 複雑である.1 次の固有振動数が高い図 9(b) においては 1 次の固有モードの影響が大きく現れていることが確認 できる.これは，模擬地震波の卓越振動数と系の固有振動数の関係から現れるものであると考えられる. なお, 片持ち条件については, 加速度応答倍率はすべての条件について先端で最大值をとっているが，両端固定条件で は，中央以外の部分で最大值をとる場合があり，構造物に初期ねじれを使用する際には，応答低減効果が得られ る部位について考慮する必要がある.

図 10 より, 模擬地震波を入力した解析結果は, 実地震波を入力した場合と同様に, 地震波の卓越振動数と系の 固有振動数の関係により加速度応答倍率に変化が見られる. 模擬地震波では, この傾向が把握しやすくなってお り，系のパラメータによっては，総ねじれ角をある值にすることで応答低減効果が得られると考えられる.

Table 4 Analysis Condition

\begin{tabular}{|c|c|c|c|c|}
\hline Material & $\begin{array}{c}\text { Natural Frequency of } \theta=0 \mathrm{rad} \\
f_{1} \mid \theta=0[\mathrm{~Hz}]\end{array}$ & $\begin{array}{c}\text { Aspect Ratio } \\
\gamma[-]\end{array}$ & $\begin{array}{c}\text { Total Twisted Angle } \\
\theta[\mathrm{rad}]\end{array}$ & $\begin{array}{c}\text { Boundary } \\
\text { Condition }\end{array}$ \\
\hline Aluminum & $0.05-20$ & $1,2,5,10,20$ & $0-8 \pi$ & $\begin{array}{c}\text { Cantilever } \\
\text { Fixed-Fixed }\end{array}$ \\
\hline
\end{tabular}

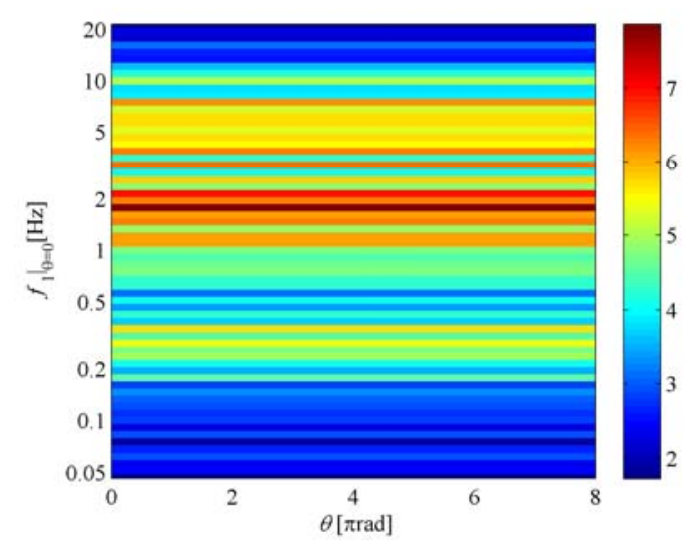

(a) $\gamma=1$

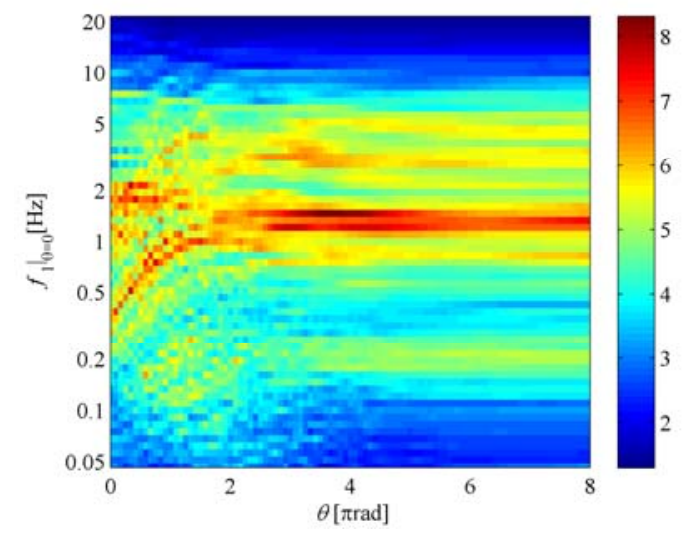

(c) $\gamma=5$

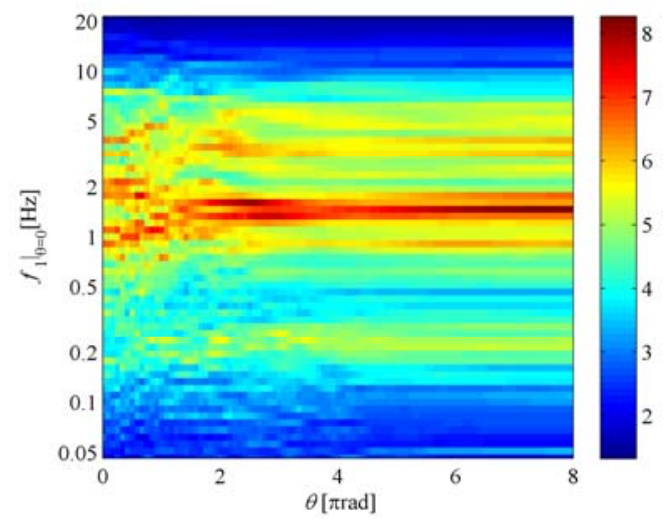

(b) $\gamma=2$

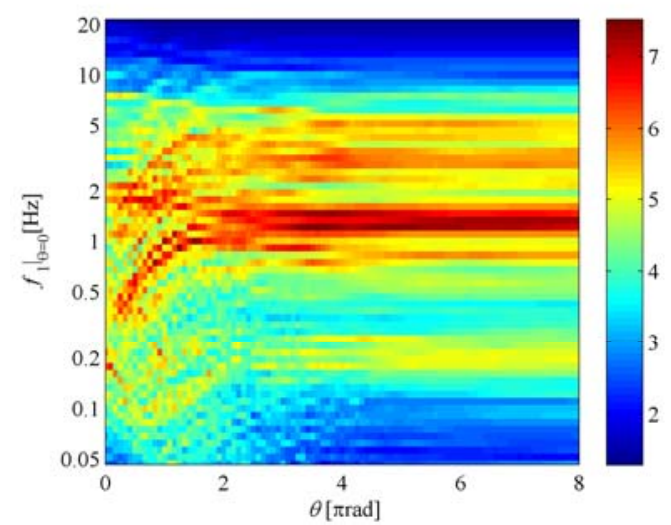

(d) $\gamma=10$

Fig. 8 The Acceleration Response Magnification by Earthquake Input (Cantilever). The acceleration response magnification is the maximum acceleration response divided by maximum input acceleration. Acceleration response magnification does not change over $4 \pi$ of total twisted angle. 


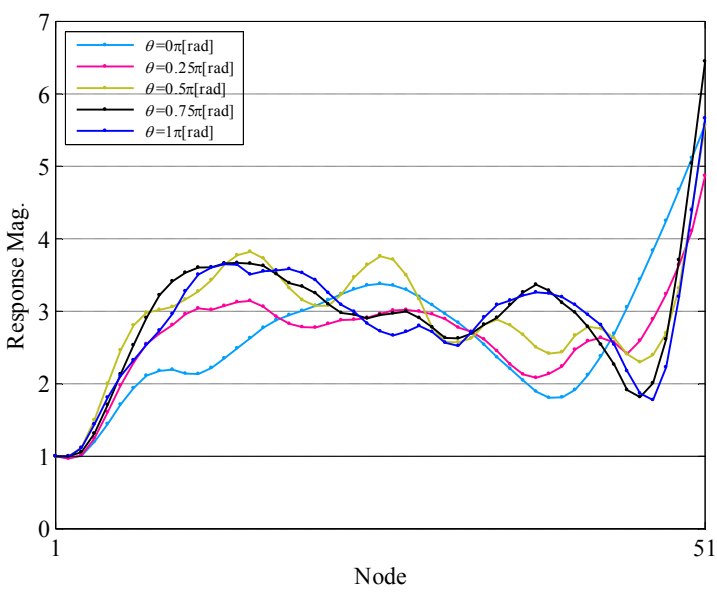

(a) $\left.f_{1}\right|_{\theta=0}=0.1[\mathrm{~Hz}]$

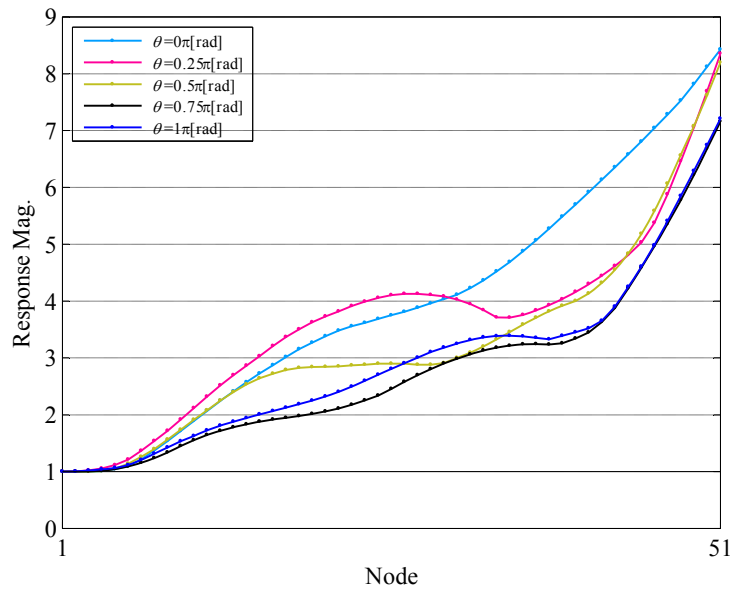

(b) $\left.f_{1}\right|_{\theta=0}=1[\mathrm{~Hz}]$

Fig. 9 Acceleration Response Magnification at Each Node (Cantilever). Left side is fixed. Fig.9(a) and (b) show the case of 1st natural frequency is $0.1 \mathrm{~Hz}$ and $1 \mathrm{~Hz}$, respectively. Influence of high frequency happens in fig.9(a), and fig.9(b) depends on 1st mode.

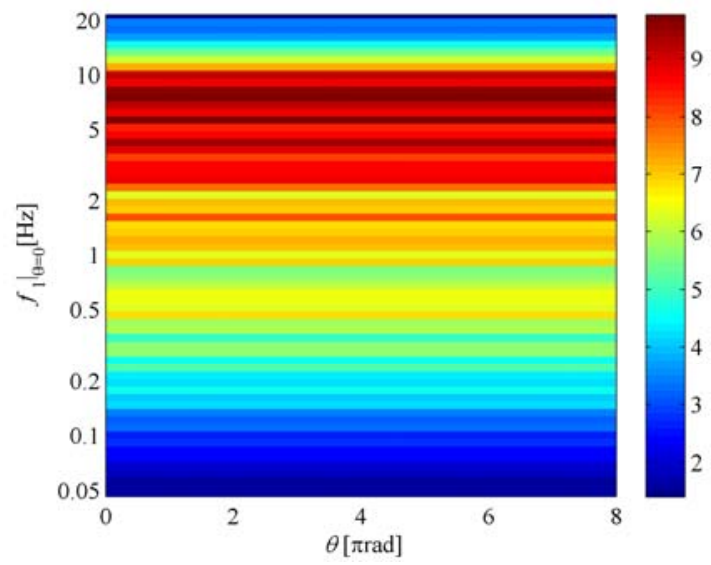

(a) $\gamma=1$

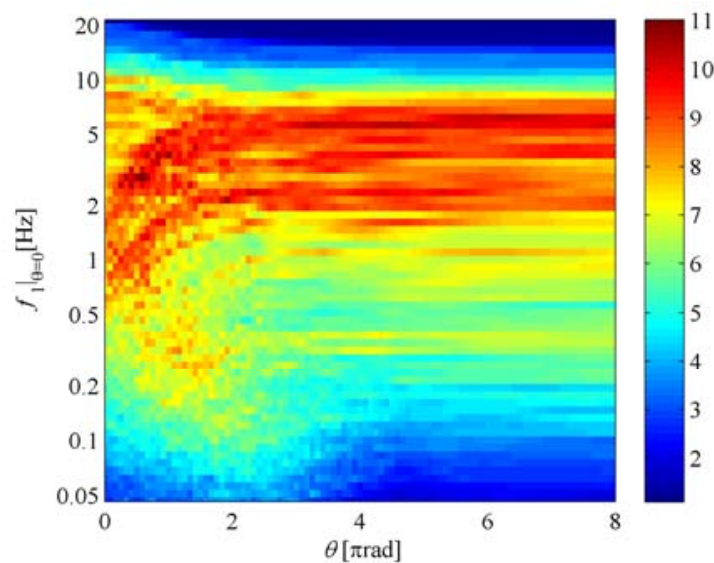

(c) $\gamma=5$

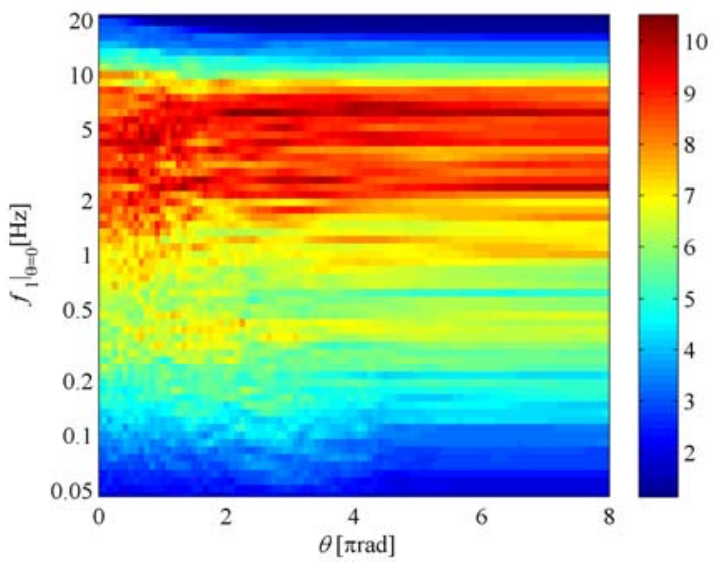

(b) $\gamma=2$

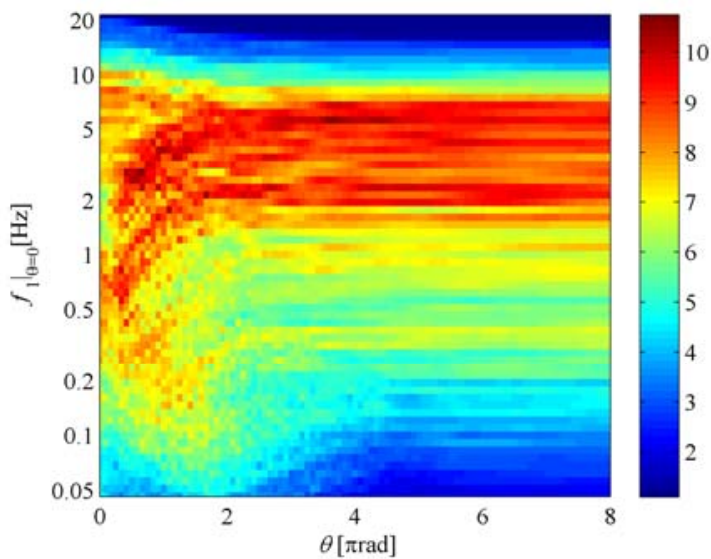

(d) $\gamma=10$

Fig. 10 Acceleration Response Magnification by Design Seismic Wave Input (Cantilever). The trend of the change of natural frequency is approximately equal to the result from actual earthquake input. 


\section{7. 応答低減マップの提案}

\section{$7 \cdot 1$ 応答低減マップの作成方法}

本研究では様々な入力波に対して加速度応答倍率の計算を行い，初期ねじれと加速度応答倍率の関係を把握し てきた。この計算により得られた結果から，初期ねじれを有効に活用するための応答低減マップを作成する．応 答低減マップは，応答低減効果の得られる領域と得られない領域を図に表すことで，応答低減効果が得られるパ ラメータの設定方法を提案するものであり，簡易耐震設計に利用可能である.

応答低減マップの作成手順を以下に示す. まず, 設計用模擬地震波を決定し, 部材の境界条件と断面辺長比 $\gamma$, 解析範囲の 1 次の固有振動数 $f_{1}$ と総衫じれ角 $\theta$ を決定する. 次に, 決定したパラメータを用いて加速度応答倍率 を計算する．この時，入力波は複数用意して加速度応答倍率の平均值を計算する. 計算した加速度応答倍率には ばらつきがあるため，移動平均を用いてばらつきを低減することで，1 次の固有振動数と総ねじれ角による加速 度応答倍率の変化の傾向を見やすくする．ねじれの無い場合に比べて応答倍率が低減している場合を応答低減効 果が有ると定義し，縦軸にねじれの無い場合の 1 次の固有振動数，横軸に総ねじれ角をとり，応答低減効果が有 る領域を白，無い領域を黒として応答低減マップを作成する.

\section{$7 \cdot 2$ 応答低減マップの利用}

図 11 に応答低減マップの作成例を示寸. 図は第 1 種地盤〜第 4 種地盤の模擬地震波を入力した場合で, 片持ち 条件，断面辺長比が 5 の部材を想定したものであり，図中の白い領域では応答低減効果が得られ，黒い領域では 応答低減効果が得られない，この図を用いることで，例えば，第 1 種地盤において，片持ち梁で 1 次の固有振動 数が $0.5[\mathrm{~Hz}]$, 断面辺長比が 5 の部材について, 初期ねじれにより応答低減効果を得る場合には, 総ねじれ角を $2 \pi$ 程度に設定すれば良いことがわかる。このように応答低減マップを利用することで，初期ねじれを簡易的に構 造物に応用することが可能となる.

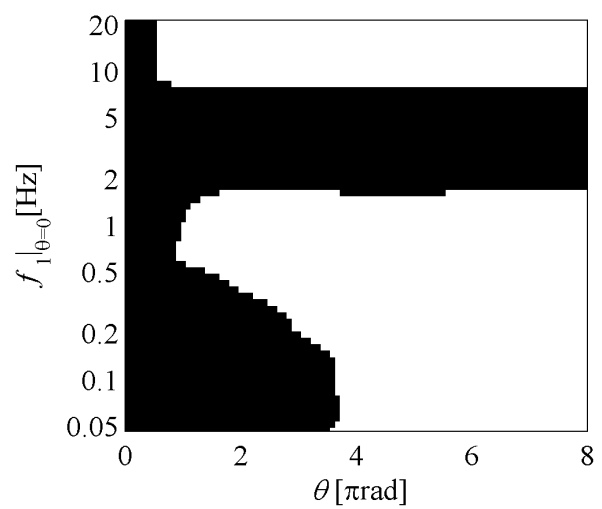

(a) Soil 1

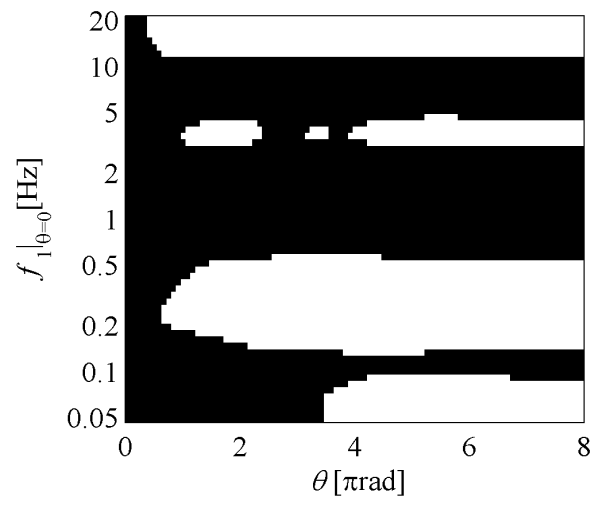

(c) Soil 3

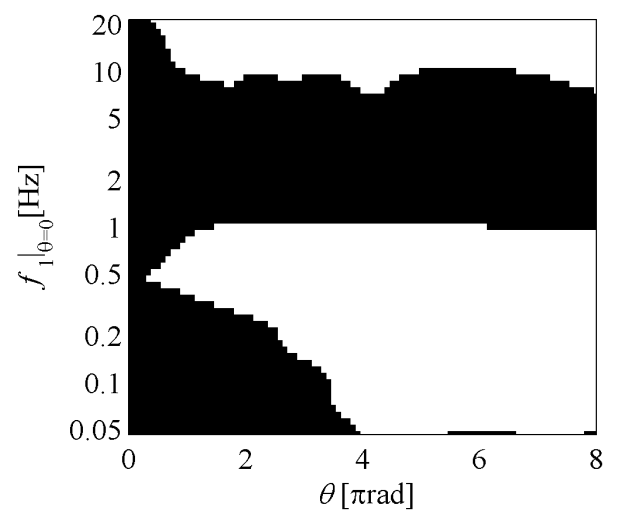

(b) Soil 2

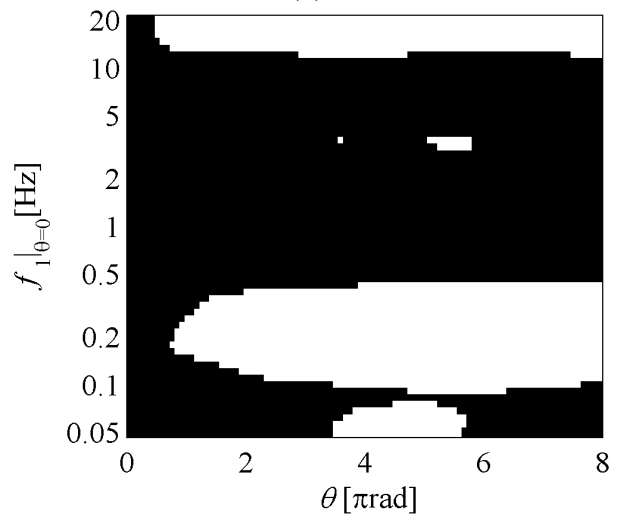

(d) Soil 4

Fig. 11 Response Reduction Map (Cantilever, $\gamma=5$ ). Fig.11(a) to (d) show the case of soil category 1 to 4, respectively. The white part of the map shows the area that response reduction effect is remarkable. Using these maps, appropriate total twisted angle can be obtained and utilized to the seismic design. 


\section{8. 結 言}

本研究では，初期ねじれを有する長柱および梁に注目し，その振動特性を明らかにするとともに振動入力に対 する応答低減効果について検討を行った，その結果，初期ねじれを有することによる固有振動数や振動モードの 変化により，条件によっては応答低減効果が得られることが明らかとなった．この応答低減効果を而震設計に適 用するために応答低減マップを提案した。 これにより，応答低減効果が得られるねじれ角を簡易推定することが 可能となった.

\section{文献}

Bathe, K. J.，Wilson, E. L.，菊池文雄訳，有限要素法の数值計算，科学技術出版社 (1996).

入江敏博，小林幸徳，機械振動学通論 第 3 版，朝倉書店 (2009).

板倉和則，築地恒夫，ねじれた厚板の自由振動，日本機械学会論文集 C 編 Vol. 59, No. 558(1993), pp. 315-321.

板倉和則，曲がりかつねじれた部分円筒曲板の自由振動（基礎理論），日本機械学会論文集 C 編，No. 95-1297

(1996), pp. 20-24.

高圧ガス保安協会，高圧ガス設備等而震設計指針 (2012).

Liu, K-C., Friend, J. and Yeo, L., The axial-torsional vibration of pretwisted beams, Journal of Sound and Vibration, Vol. 321 (2009) pp. 115-136.

大崎順彦，新・地震動のスペクトル解析入門，鹿島出版会 (2004).

日本機械学会編，振動工学におけるコンピュータアナリシス，コロナ社 (1990).

靹田顕章, 渡邊鉄也，田中基八郎，長周期摩擦系応答スペクトルに関する研究，日本機械学会論文集 C 編，Vol. 73, No. 730 (2007), pp. 93-98.

渡邊鉄也，三森友彦，鈴木浩平，清水信行，小川信行，箕輪親宏，摩擦サポートを有するプラント配管系の振動

実験，日本機械学会論文集 C 編，Vol. 58, No. 552 (1992), pp. 17-23.

渡邊鉄也, 鈴木浩平, 三森友彦, 清水信行, 支持部にがた・摩擦を有するプラント配管系の地震応答, 日本機械 学会論文集 C 編，Vol. 62, No. 595 (1996), pp. 63-68.

渡邉鉄也, 鈴木浩平, 面内しゅう動を有する摩擦支持配管系の地震応答, 日本機械学会論文集 C 編, Vol. 64, No. 617 (1998a), pp. 64-69.

渡邊鉄也，鈴木浩平，摩擦支持配管系の地震応答解析（摩擦系応答スペクトルを用いた最大応答の推定），日本機 械学会論文集 C 編, Vol. 64, No. 619 (1998b), pp. 87-92.

渡邊鉄也, 鈴木浩平, 摩擦系応答スペクトルを用いた配管系の等価減衰比推定法, 日本機械学会論文集 C 編, Vol. 66, No. 642 (2000), pp. 87-92.

渡邊鉄也，鞆田顕章，田中基八郎，長周期摩擦系における応答低減マップ，日本機械学会論文集 C 編，Vol. 72, No. 722 (2006), pp. 151-156.

渡邊鉄也，武田知也，田中基八郎，エネルギに基づくがた系の応答低減マップ，日本機械学会論文集 C 編，Vol. 74, No. 738 (2008), pp. 84-89.

渡邊鉄也, 中山仁志, 靹田顕章, 田中基八郎, 弾塑性系応答スペクトルに関する研究, 日本機械学会論文集 C編, Vol. 75, No. 759 (2009), pp. 33-40.

山田貴博, FEM における構造モデリングーソリッド要素と構造要素（はり，シェル）の選択一, 精密工学会誌, Vo. 77, No. 9, (2011).

ツィエンキーヴィッツ O. C., テイラー R. L., 矢川元基訳, マトリックス有限要素法 [改訂新版], 科学技術出 版社 (1996).

\section{References}

Bathe, K.J., Wilson, E.L. and Kikuchi, F., Numerical methods in finite element analysis, Kagaku Gijutsu Shuppan, inc. (1996)(in Japanese).

Irie, T. and Kobayashi, Y., Mechanical vibration, Vol.3, Asakura Publishing Co., Ltd., (2009)(in Japanese).

Itakura, K. and Tsuiji, T., Free vibration of pre-twisted thick plates, Journal of the Japan Society of Mechanical Engineers, Series C, Vol.59, No.558 (1993), pp.7-13(in Japanese).

Itakura, K., Free vibrations of curved and twisted cylindrical panels (fundamental theory), Journal of the Japan Society of 
Mechanical Engineers, Series C, Vol.62, No.599 (1996), pp.20-24 (in Japanese).

KHK, Seismic design standard for the high pressure gas facilities (2012).

Liu, K-C., Friend, J. and Yeo, L., The axial-torsional vibration of pretwisted beams, Journal of Sound and Vibration, Vol. 321 (2009), pp. 115-136.

Osaki, Y., New primer of spectrum analysis for seismic motion, Kajima Institute Publishing Co., Ltd. (2004).

The Japan Society of Mechanical Engineers ed., Computer analysis for vibration engineering, Corona Publishing Co., Ltd. (1990)(in Japanese).

Tomoda, A., Watanabe, T. and Tanaka, K., Study on friction response spectrum under long period system, Transactions of the Japan Society of Mechanical Engineers, Series C, Vol.73, No.730 (2007), pp.93-98(in Japanese).

Watanabe, T., Mitsumori, T., Suzuki, K., Shimizu, N., Ogawa, N. and Minowa, C., Vibration test of plant piping system having friction support, Transactions of the Japan Society of Mechanical Engineers, Series C, Vol.58, No.552 (1992), pp.17-23 (in Japanese).

Watanabe, T., Suzuki, K., Mitsumori, T. and Shimizu, N., Seismic responses of plant piping system having friction and vibro-impact characteristics, Transactions of the Japan Society of Mechanical Engineers, Series C, Vol.62, No.595 (1996), pp.63-68 (in Japanese).

Watanabe, T. and Suzuki, K., Seismic responses of piping system with friction sliding on a plane, Transactions of the Japan Society of Mechanical Engineers, Series C, Vol.64, No.617 (1998a), pp.64-69 (in Japanese).

Watanabe, T. and Suzuki, K., Seismic response analysis of piping system with friction support (maximum response estimation using frictional response spectrum), Transactions of the Japan Society of Mechanical Engineers, Series C, Vol.64, No.619 (1998b), pp.87-92(in Japanese).

Watanabe, T. and Suzuki, K., Estimation of equivalent damping ratio using friction response spectrum , Transactions of the Japan Society of Mechanical Engineers, Series C, Vol.66, No.642 (2000), pp.87-92 (in Japanese).

Watanabe, T., Tomoda, A. and Tanaka, K., Response reduction map under long period friction system , Transactions of the Japan Society of Mechanical Engineers, Series C, Vol.72, No.722 (2006), pp.151-156(in Japanese).

Watanabe, T., Takeda, T. and Tanaka, K., Response reduction map of gap system based on energy, Transactions of the Japan Society of Mechanical Engineers, Series C, Vol.74, No.738 (2008), pp.84-89(in Japanese).

Watanabe, T., Nakayama, H., Tomoda, A. and Tanaka, K., Study on response spectrum of elast-plastic system, Transactions of the Japan Society of Mechanical Engineers, Series C, Vol.75, No.759 (2009), pp.33-40(in Japanese).

Yamada T., Introduction to precision engineering: on modeling of structures in the finite element method: difference in usage between solid and structural (beam and shell) elements, Journal of the Japan Society of Precision Engineering, Vol. 77, No. 9, (2011)(in Japanese).

Zienkiewicz, O. C., Taylor, R. L. and Yagawa, G., The finite element method, Kagaku Gijutsu Shuppan, inc.(1996)(in Japanese). 